\title{
New Textbooks
}

\section{The Twitter Machine \\ Reflections on Language \\ NEIL SMTTH}

'A very elegant achievement... It is popularization of science in the very best sense, a feat not easy to achieve. I read it through with pleasure and anticipation, and I expect that others will as well.' Noam Chomsky

288 pages, hardback 627.50 (0631 169253) paperback 69.50 (0 631169263$)$

\section{(1) Bilingualism SUZANNE ROMAINE}

Written from a combined sociolinguistic and psycholinguistic perspective, Professor Romaine's new book is an accessible guide to, and survey of, developments in the study of bilingualism for linguists, educators and psychologists.

384 pages, hardback E35.00 (0631 152253 ) paperback 610.95 (0 631152261$)$

\section{Sociolinguistics and Second Language Acquisition DENNIS R. PRESTON}

Professor Preston assesses the relationship between Second Language Acquisition and sociolinguistics, focusing in particular on the findings of quantitative sociolinguistics. The book also deals with the usefulness of sociolinguistic data to the practical jobs of designing curricula and materials and training teachers.

352 pages, hardback $\mathbf{6 3 5 . 0 0}$ (0 631152458$)$

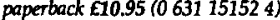

\section{The Pronunciation of English}

A Course Book in Phonology

\section{CHARLES W. KREIDLER}

'An excellent introduction to what phonology is about, and a comprehensive textbook for native and non-native students of the English language. A useful and timely book which I expect to hold the field for a considerable time.' Max Wheeler, University of Liverpool

400 pages, hardback $€ 30.00(0631162186)$ paperback $E 10.95$ (0 63116219 4)

\section{Autosegmental and Metrical Phonology An Introduction JOHN GOLDSMITH}

This is the first complege introduction to the current generative theoretical phonology, presenting both a general introduction to the two theories of phonological representation that lie at the centre of current research, and a critical evalutation of the central issues and tenents of lexical phonology. 392 pages, hardback $\mathbf{E 4 0 . 0 0}(0631136754)$ paperback $€ 14.95$ (0 63113676 2)

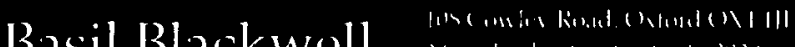

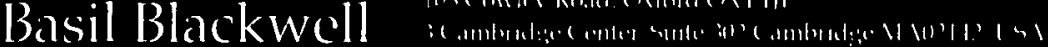




\section{Cambridge}

\section{Bilinguality and Bilingualism}

\section{JOSIANE F. HAMERS and MICHEL BLANC}

This book studies the way in which bilingualism develops its social, neurological and psychological foundations, and its consequences. It also explores the wider issues of language in contact and the applications of bilingual research to language teaching and planning.

$£ 35.00$ net HC 0521332796400 pp.

\section{The Limits to Debate}

A Revised Theory of Sematic Presupposition

\section{NOEL BURTON-ROBERTS}

Noel Burton-Roberts presents a very simple and genuinely new semantic definition which is more general than the standard definition of presupposition defined by Frege and Strawson and which leads to a semantics more easily interpreted as two-valued with gaps.

€27.50 net $0521361508288 \mathrm{pp}$.

Cambridge Studies in Linguistics 51

\section{Predication Theory}

A Case Study for Indexing Theory

DONNA JO NAPOLI

The author presents a convincing case for viewing the notion of predicate as a semantic primitive which cannot be defined by looking simply at the lexicon or syntactic structure and offers a theory of predication where the key to the subject-predicate relationship is theta-role assignment.

$\notin 35.00$ net $\mathrm{HC} \quad 0521352983 \quad 380 \mathrm{pp}$.

$£ 15.00$ net $\mathrm{Pb} \quad 0521368200$

Cambridge Studies in Linguistics 50

\section{Pidgins and Creoles Volume II}

\section{Reference Survey}

JOHN HOLM

This second volume provides an overview of the socio-historical development of each of some one hundred known pidgins and creoles. Each variety is grouped according to the language from which it draws its lexicon and John Holm explains the historical and linguistic reasons for this organisation.

$£ 42.50$ net $\mathrm{Hc} \quad 0 \quad 521350891 \quad 470 \mathrm{pp}$.

$£ 17.50$ net $\mathrm{Pb} \quad 0521359406$

Cambridge Language Surveys

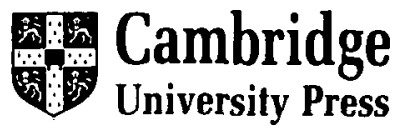

The Edinburgh Building, Cambridge CB2 2RU 


\section{Cambridge}

\section{Sign Languages of Aboriginal Australia}

Cultural, Semiotic and Communicative Perspectives

ADAM KENDON

A unique study of the complex gesture systems used by Australian Aborigines which provides the basis for a compelling descriptive, comparative and theoretical discussion of these unusual sign languages.

£30.00 net 0521360080500 pp.

\section{The Grammar of Modern Hebrew}

\section{LEWIS GLINERT}

In this pioneering work Lewis Glinert has provided a description of Hebrew as it is really spoken and written in Israel today. The principal emphasis is on syntax and the author pays particular attention to functional distinctions, giving equal weight to colloquial and formal usage.

E55.00 net 0521256119600 pp.

\section{Investigating Obsolescence}

Studies in Language Contraction and Death

Edited by NANCY DORIAN

This volume is the first attempt to provide an overview of current research into the study of contracting and dying languages and studies some of the crucial methodological and theoretical issues to which it has given rise.

f37.50 net $052132405 \times 457$ pp.

Studies in the Social and Cultural Foundations of Language 7

\section{Explorations in the Ethnography of Speaking}

\section{Second Edition}

Edited by RICHARD BAUMAN and JOEL SHERZER

First published in 1974, this collection of classic case studies in the ethnography of speaking had a formative influence on the field. Now reissued, the collection includes a major new introduction which traces the subsequent development and indicates the directions of future research.

$£ 40.00$ net HC 0521370639500 pp.

E15.00 net Pb 0521379334

Studies in the Social and Cultural Foundations of Language 8

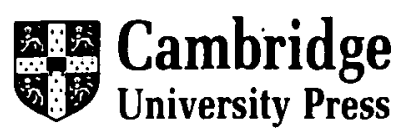

The Edinburgh Building, Cambridge CB2 2RU 


\section{Cambridge}

Now in paperback

\section{Linguistics: The Cambridge Survey}

Volume 1 - Linguistic Theory: Foundations

Volume II - Linguistic Theory: Extensions and Implications

Volume III - Language: Psychological and Biological Aspects

Volume IV - Language: The Socio-cultural Context

\section{Edited by FREDERICK J. NEWMEYER}

Linguistics: The Cambridge Survey is a comprehensive introduction to current research in all branches of the field of linguistics, from syntactic theory to ethnography of speaking, from signed language to the mental lexicon, from language acquisition to discourse analysis. Each chapter has been written by a specialist particularly distinguished in his or her field who has accepted the challenge of reviewing the current issues and future prospects in sufficient depth for the scholar and with sufficient clarity for the student.

Each volume can be read independently and has a particular focus. Volume I covers the internal structure of the language faculty itself, while Volume II considers the evidence for, and the implications of, a generativist approach to language. Psycholinguistics and neurolinguistics are covered in Volume III, and Volume IV concentrates on sociolinguistics and the allied fields of anthropological linguistics and discourse and conversation analysis.

Several of the chapters concentrate on the interface between different aspects of linguistic theory or the boundaries between linguistic theory and other disciplines. Thus in both its scope and in its approach the Survey is a unique and fundamental work of reference. It fulfils the principal aim of providing a wealth of information, insight and ideas that will excite and challenge all readers with an interest in linguistics.

'... an ambitious and timely project ... impressive scope and high level of competence of individual contributions'.

Noam Chomsky

'... these books are simply excellent. The contributions are informed, up to date and lucid ... the editor is to be congratulated for the high standards that are maintained throughout. The tremendous intellectual energy and the excitement of the field come through strongly'. The Times Higher Education Supplement

$228 \times 152 \mathrm{~mm}$ each volume tables and line diagrams in all volumes

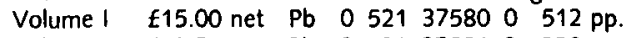

Volume II $€ 12.50$ net $\mathrm{Pb} \quad 0 \quad 52137581 \quad 9 \quad 328$ pp.

Volume III $€ 12.50$ net $\mathrm{Pb} \quad 0 \quad 521375827368$ pp.

Volume IV $£ 12.50$ net $\mathrm{Pb} \quad 0 \quad 521375835304$ pp.

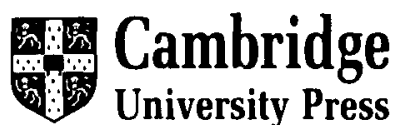

The Edinburgh Building, Cambridge CB2 2RU 
Breaking new ground in linguistics... Language Variation and Change

A new journal from Cambridge University Press

Over the past 20 years the study of linguistic variation in both speech and writing has become a major branch of linguistics. Language Variation and Change is the only journal dedicated exclusively to this significant and developing area. It will focus on:

- linguistic structure

- mother-tongue or language-of-choice as an index of social relationships and structure

- language policy and planning

ethnography of speaking

- study of speech acts and conversational roles

The journal will publish original research reports based on the data of linguistic production, both oral and written, using historical and contemporary sources.

Volume 1, 1989 (Triannual) ISSN 0954-3945

Subscription (outside USA and Canada)

$£ 15$ for individuals; $£ 30$ for $U K$ institutions; $£ 32$ for institutions

elsewhere; Airmail $£ 7.50$ per year extra

Subscription in USA and Canada

$\$ 25$ for individuals; $\$ 50$ for institutions

For further information, please contact Journals Publicity

Department, Cambridge University Press, FREEPOST* The

Edinburgh Building, Shaftesbury Road, Cambridge CB2 2RU,

England. ("No stamp needed if posted in the UK)

In USA and Canada, please contact Cambridge University Press,

32 East 57th Street, New York, NY 10022

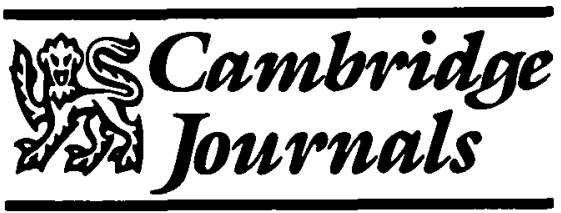




\section{Doing phonology}

Observing, recording, interpreting

\section{JOHN KELLY and JOHN LOCAL}

Two phonologists discuss how they observe and record speech and describe the structures of spoken language. The reader is taken through these processes and introduced to the analytical techniques involved. Doing phonology differs from other works in the field by giving a personal perspective on the first-hand study on natural speech. It deals with material from a wide range of languages and includes spontaneous conversation, children's speech and pathological speech thus providing an instructive and stimulating text.

$1989 \quad 286$ pp. 0719028949

Hb £25.00

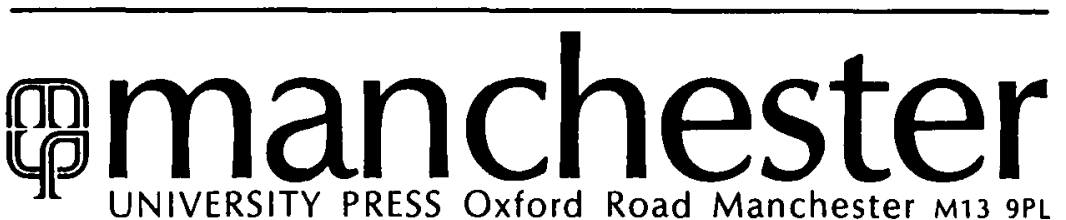




\title{
new journal
}

\section{COGNITIVE LINGUISTICS}

Editor-in-Chief: Dirk Geeraerts (Leuven)

\author{
Editorial Board: \\ Hans Basboll \\ René Dirven \\ John Haiman \\ Tomasz Krzeszowski \\ George Lakoff \\ Ronald Langacker \\ Stephen Levinson \\ Richard Rhodes \\ Pieter Seuren
}

This new journal presents a forum for all kinds of linguistic research on the interaction between language and cognition. Cognitive linguistics focusses on language as an instrument for organizing, processing, and conveying information, and the journal is devoted to high-quality research on topics such as:

- the structural characteristics of natural language categorization (such as prototypicality, cognitive models, metaphor, and imagery);

- the functional principles of linguistic organization (such as iconicity);

- the conceptual interface between syntax and semantics;

- the relationship between language and thought, including matters of universality and language specificity;

- the experiential background of language-in-use, including the cultural background, the discourse context, and the psychological environment of linguistic performance.

The journal has an explicitly interdisciplinary orientation, not only in the sense that cognitive linguistics tries to incorporate relevant research from other cognitive disciplines, but also because the journal will highlight the contribution of linguistics to Cognitive Science.

\section{Subscription information:}

$14.8 \times 22.5 \mathrm{~cm}$. 1 volume per year published in four issues. Approx. 400 pages in total. ISSN 0936-5907

Vol. 1 (1990) Institutions DM 154,-; approx. $£ 51.50$

Single issue DM 42,-; approx. $£ 14.00$

plus postage

Members of the International Cognitive Linguistics Association will receive the journal automatically.

Subscriptions and sample copies may be ordered through your local bookseller or directly from the publisher.

Prices are subject to change without notice.

\section{mouton de gruyter berlin - new york}


m Approaches to Semiotics

Editors:

m Thomas A. Seboek, Indiana University, Bloomington .

Roland Posner, Technische Universität Berlin .

Alain Rey, Paris

Robert M. Strozier

Saussure, Derrida and the Metaphysics of Subjectivity

1988. XII, 304 pages. Cloth DM 128,-; approx. $£ 42.80$ ISBN 3110112817 (AS 80)

This research monograph deals primarily with Ferdinand de Saussure and Jacques Derrida. Saussure who is seen as "The Father of Structuralism", is placed within the intellectual tradition of the twentieth century, and his "Cours de linguistique générale" is submitted to methodical analysis.

The second section of the work introduces Derrida and his deconstruction of Saussure. Derrida is used to further the analysis of Saussure, but also as a means to counter Derrida's own claims.

Julio C. M. Pinto

The Reading of Time:

A Semantico-Semiotic Approach

m

1989. X, 162 pages. Cloth DM 98,-; approx. £ 32.80 ISBN 3110113066 (AS 82)

Dn This monograph proposes a model that can account for the reader's strategies in the interpretation of narrative time. It integrates contributions from semantics and textlinguistics with the semiotic of Charles S. Peirce, from which it is ultimately derived.

Unlike other accounts of narrative time, which rely on typologies of plot organization and structuring devices, this work formulates a theory that aims at both descriptive and explanatory adequacy by approaching the narrative from the standpoint of the reader.

Prices are subject to change

UK agents:

Frank 1. Kevlin Publishers 40 Barrow Street, Streatham LONDON SW 16 5PF

Phone (01) 7696564

mouton de gruyter 


\section{im Approaches to Semiotics}

Editors:

Thomas A. Seboek, Indiana University, Bloomington .

Roland Posner, Technische Universität Berlin .

Alain Rey, Paris

Benjamin Lee · Greg Urban (Editors)

\section{Semiotics, Self, and Society}

1989. XVIII, 311 pages. Cloth DM 118,-; approx. £ 39.50 ISBN 3110119781 (AS 84)

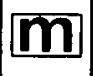

m

m

m

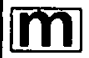

m

m

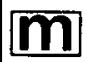

m

The essays, written by anthropologists and a psychoanalyst, are devoted to the problem of self in language, discourse and culture. They explore the range of sign phenomena, from pronominal usage to literature and philosophy, which form the basis for culturally-specific self constructs. Each contribution reflects, in varying degrees and ways, the influence of Milton Singer, in whose honor the volume was originally conceived, and who is himself a contributor.

The volume includes an introduction by the editors and a preface by Thomas A. Seboek.

Thomas A. Seboek · Jean Umike-Seboek (Editors) The Semiotic Web 1988

1989. X, 430 pages. With 8 illustrations. Cloth DM 198,-; approx. $£ 66.00$ ISBN 3110122227

(AS 85)

The third volume in this series presents developments in the field of Semiotics in 1988. It includes articles focussing on the work of M. M. Bakhtin, Paul Boissac and Cesare Segre, among others. Thure von Uexküll contributed an article on Jakob von Uexküll's Environmental Theory and Augusto Ponzio discusses Semiotics and Marxism. Other topics include the semiotics of old age, the semiotics of rhetoric, cinesemiotics, and semiotics and artificial intelligence.

\section{mouton de gruyter}

Berlln · New York 


\title{
Contributions to the Sociology of Language
}

Editor: Joshua A. Fishman

\section{Harald Haarmann}

\section{Symbolic Values of Foreign Language Use}

\section{From the Japanese Case}

\author{
to a General Sociolinguistic Perspective
}

1989. XIV, 291 pages. With 52 illustrations. Cloth DM 128,-; approx. $£ 42.80$ ISBN 3110117126 (CSL 51)

$\mathbf{m}$

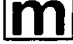

m

$\mathbf{m}$
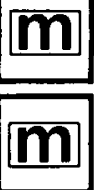

$\mathbf{m}$
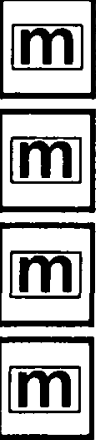

$\mathbf{m}$

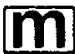

This research monograph describes the role of world languages in symbolic functions in societies where these languages are non-native. Because of the cultural contrasts, the role of English in Japan, where it is used in marketing and mass media entertainment, is of particular interest in this study.

The symbolic value of English, for example, is its use as a symbol of modernity, where as French expresses elegance, femininity and refined taste and German has the connotation of "Gemütlichkeit". These phenomena are viewed within a sociolinguistic framework of language attitudes and cultural stereotypes.

The symbolic functions of foreign languages in communities of non-native speakers can be understood as a reflection of a worldwide trend towards internationalization. This is illustrated for a number of countries, including Finland, Germany, and Malta. This work provides a model for analysis of such functions.

Hywel Coleman (Editor)

\section{Working with Language}

\section{A Multidisciplinary Consideration of Language Use in Work Contexts}

1989. XII, 617 pages. Cloth DM 218,-; approx. $£ 73.00$ ISBN $311011643 \mathrm{X}$ (CSL 52)

This collection of 19 papers presents new insights into various aspects of language use in work contexts which are wide ranging methodologically, geographically and in occupational terms. Thus, evidence presented comes not only from North America and Western Europe, but also from countries from Peru to Japan. A wide range of occupations is considered, ranging form airline pilots and medical researchers to teachers, civil servants and even ragpickers. This collection appears at a time when the nature of work as full-time paid employment is being questioned, both in industrialized and agricultural societies, and shows the necessity of reconsidering the relationship between language and work by those concerned with language use in work context.

By bringing together the work of specialists in different fields, it crosses disciplinary boundaries, in particular by bringing together sociolinguistics and applied linguistics (especially fields associated with English language teaching.

\section{mouton de gruyter}




\title{
Contributions to the Sociology of Language
}

\author{
Editor: Joshua A. Fishman
}

Ofelia García - Ricardo Otheguy (Editors)

m

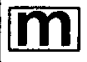

m

m

m

$\mathbf{m}$

m

m

m

m

m

m

m

m

\section{English across Cultures Cultures across English} A Reader in Cross-Cultural Communication

1989. XXII, 492 pages. With 7 illustrations. Cloth DM 178,-; approx. $£ 59.50$ ISBN 3110118114

(CSL 53)

This collection of articles sets out to examine verbal and written exchanges in English when they occur in the context of conflicting community norms. Complex sociolinguistic situations arise when the use of English by non-native speakers leads to a false sense of mutual intelligibility.

The papers, prepared by scholars from all over the world, are grouped into four sections, according to the type of sociolinguistic situation that creates the communicative interference, and contain work from the areas of pragmatics, sociology of language, dialectology and sociolinguistic variation, and social psychology. Both micro-studies of intercultural communication and studies of the macro processes that affect intercultural communication are included.

\section{Björn H. Jernudd · Michael J. Shapiro (Editors) \\ The Politics of Language Purism}

1989. VI, 250 pages. Cloth DM 118,-; approx. $£ 39.50$ ISBN $311011710 \mathrm{X}$ (CSL 54)

In this collection of invited papers, linguistic, sociolinguistic, literary and political approaches have been brought together to describe and analyze language purism and its purposes.

In the 13 contributions by this international group of scholars, these approaches are combined with observations and case studies from different countries around the world, many of them in Asia.

Purism is present in all cultural activities to a degree, since it asserts a society's sense of uniqueness and authenticates tradition.

Purism of language identifies and differentiates users of one language from those of another, and it provides not only the ideology but also the idiom and the basis of evaluation for language correction in discourse to constitute "pure" language and to demarcate it from "impure" language.

\section{mouton de gruyter}




\section{Contributions to the Sociology of Language}

Editor: Joshua A. Fishman

Mary Ritchie Key · Henry M. Hoenigswald (Editors)

\section{General and Amerindian Ethnolinguistics}

In Remembrance of Stanley Newman

1989. XVI, 502 pages. Cloth DM 198,-; approx. $£ 66.00$ ISBN $311011822 \mathrm{X}$

(CSL 55)

The work of Stanley Newman (1905-1984) spanned six decades of this century, beginning with his early work with Edward Sapir up to his terms as VicePresident and President-elect of the Linguistic Society of America. During his career, he worked on many languages and language families of North America and Mexico.

This volume represents a segment of the history of the unfolding of linguistics in the United States, covering a wide range of linguistic topics, from phonology and grammar to oral traditions and ethnological studies. These reflect the prominence of the Amerindian languages in the development of linguistics there, is distinguished from the history of linguistics in other parts of the world.

William Shipley (Editor)

$\mathbf{m}$

\section{In Honor of Mary Haas}

From the Haas Festival Conference on Native American Linguistics 1989. XIV, 826 pages. Cloth DM 288,-; approx. $£ 96.00$ ISBN 3110111659

This volume presents 36 selected papers on Native American linguistics and anthropological linguistics from those presented in honor of Mary Haas at the Haas Festival Conference in June 1986.

Mary Haas, a student of Sapir's and co-founder of the Department of Linguistics at the University of California at Berkeley, was responsible for the amassing of vast amounts of data from many dying languages which would otherwise have been lost, and for this reason most of her students and many other eminent Americanist scholars gathered in her honor. 


\section{Athapaskan Linguistics}

\section{Current Perspectives on a Language Family}

1989. VIII, 645 pages. With 1 map. Cloth DM 218,-; approx. $£ 73.00$ ISBN 3110111667

DI (Trends in Linguistics. State-of-the-Art Reports 16)

This volume represents an attempt to show the present state of the art in the study of this group of Native American language spoken in a large part of Alaska, as well as on the California coast and the American Southwest (including such languages as Navajo, Apache, and Hupa). These languages are characterized by a particularly complex verb morphology.

[1] The lengthy introduction by the editors gives a general overview of areas that have been important in the field of Athapaskan studies in the past 25 years, and provides the reader with the context in which the following contributions can be seen. The papers themselves deal with diachronic linguistics, phonology and morphology, syntax, discourse and ethnolinguistics, and have been prepared by leading scholars in the field.

\section{Keren Rice}

\section{A Grammar of Slave}

1989. XLIV, 1370 pages. Cloth DM 320,-; approx. £ 107.00 ISBN 3110107791 (Mouton Grammar Library 5)

Slave (Dene) is a Native American language of the Athapaskan family spoken in Canada, and this reference grammar deals with the dialects spoken in the Northwest Territories.

The goal of this work is to provide as complete a description of this language as possible. It includes phonetics, phonology, morphology, syntax, and semantics, as well as texts with interlinear glosses and translations and a dictionary. Languages of this family have a particularly complex verb morphology, so the section on the verb in Part 3, devoted to lexical categories, is extensive. Part 4 then presents an overview of a model for Slave grammar. Part 5 deals with syntax, including word order, co-reference, tense and aspect and complementation. 


\author{
Editor: Werner Winter
}

\title{
Olga Miseska Tomić (Editor)
}

\section{Markedness in Synchrony and Diachrony}

\author{
1989. X, 412 pages. Cloth DM 178,-; approx. $£ 59.50$ ISBN 3110117800 \\ (TLSM 39)
}

This collection of 19 papers deals with markedness, which refers to opposition in language units of any kind: sounds, words, sentences, or structural parts of sentences. Originally the theory dealt primarily with phonology, but syntactic issues now prevail.

The collection presents a synthesis of current, for the most part European, work on markedness. The development is traced, and the basic pertinent notions are redefined in the light of current trends in linguistics.

Although the justifiability of the markedness hypothesis has been questioned, the authors of this volume maintain that this is not due to the markedness relationship per se, but rather to conflation of oppositions and indiscriminate uniformity of application in different domains.

\section{Jan W. F. Mulder}

\section{Foundations of Axiomatic Linguistics}

1989. XII, 475 pages. With numerous figures and tables.

(TLSM 40)

This work presents a new theoretical approach to the study of languages, and differs from other approaches in three major respects.

The methodology of the theory, a variant of Popper's hypothetico-deductive method, could be termed "negativist", in order to differentiate it from the "positivist" tradition the author sees as prevalent in European and American linguistics.

The theory is axiomatically based, closely reasoned, and simple in relation to its adequacy, thus making it a powerful theory.

Finally, the theory, in close conjunction with the methodology, is the sole instrument in the description of languages.

Illustrated by examples from European and Oriental languages, the work gives a comprehensive introduction to the theory, deals with phonology and morphology (in chapter V), and discusses syntax in general, as well as presenting a detailed description of English syntax (chapters VI and VII). The "sentential level" is also covered (chapter VI), while chapter VIII presents the axioms and definitions, i. e., the whole of the theory in compact form.

\section{mouton de gruyter}




\title{
The New Sound of Indo-European
}

In Essays in Phonological Reconstruction

1989. XVI, 300 pages. Cloth DM 138,-; approx. $£ 46.00$ ISBN 3110105365 (TLSM 41)

The 30 articles and discussion papers in this volume address two of the most influential theories in the field of Indo-European phonology, the Laryngeal Theory and the Glottalic Theory.

Most papers analyze and support versions of these theories, but there are also some which defend more traditional reconstructions or alternative views. Since both theories will remain major research areas in the future, many discussions in Indo-European phonology will start from the contributions to this volume. The stimulus for this collection was provided by the international workshop "Reconstructions of the Proto-Indo-European sound system and their consequences" which took place in connection with the Seventh International Conference for Historical Linguistics in Pavia in 1985.

\section{Klaus Schubert (Editor) (in collaboration with Dan Maxwell) \\ Interlinguistics}

\author{
Aspects of the Science of Planned Languages \\ 1989. X, 348 pages. Cloth DM 148,-; approx. £49.50 ISBN 3110119102 \\ (TLSM 42)
}

This volume is addressed both to those who know nothing about interlinguistics and to those who are looking for an up-to-date overview of this branch of science. It will contain contributions by interlinguistics in Europe, Asia, and America and will cover a wide range of specific approaches to planned languages.

The topics will include: the opposition between planned and ethnic language, as well as the semiotic and sociolinguistic implications of this opposition; the interaction of planned languages and language planning; construction principles vs. natural language change in a second-language community; cognitive and communicative competence in a planned language; literary expressiveness and style variation; implications for universal grammar and planned languages as a laboratory tool for cross-linguistic investigations into word formation; international terminological standardization; and Esperanto as a language of knowledge representation and advanced semantic pragmatic meaning processing in machine translation.

Prices are subject to change

UK agents:

Frank I. Kevlin Publishers 40 Barrow Street, Streatham LONDON SW 16 SPF

Phone (01) 7696564

mouton de gruyter

Berlin - New York 


\title{
THE LINGUISTICS ASSOCIATION OF GREAT BRITAIN
}

\author{
List of papers given at the Joint Meeting of LAGB and the Irish Association for Applied \\ Linguistics, Belfast, 10-12 April 1989
}

Linguistics Association Lecture:

D. Dowty (University of Ohio): Thematic relations, thematic roles, and discourse structure Papers on Linguistics:

B. Aarts (UCL): The analysis of prevent-type verbs in a GB framework

R. Cann and $M$. Tait (Edinburgh): Free relatives revisited

M. Charette (SOAS, London): Vowel harmony in Khalka Mongolian

K. Cooper (Edinburgh): Word order in bare infinitival complement constructions in Swiss German

J. Delin (Edinburgh): The focus structure of $i t$ clefts

R. Kaufmann (UCL): Hedged utterances

J. Kaye (SOAS, London): What happened to Dialect 'B'?

R. Kempson (SOAS, London): Input systems: anaphora, ellipsis and operating-binding

G. King (Reading): Time adverbials in coherent discourse

A. Lascarides (Edinburgh): A solution to the imperfective paradox

S. Levinsohn (SIL): Left dislocation of temporary topics

J. Miller (Edinburgh): Roles, conceptual structure and grammar

V. Žegarac (UCL): The progressive - a relevance-theoretic account

Papers on Hiberno-English:

G. Broderick (Mannheim): Language contact in Connemara : a view from Germany

E. Douglas-Cowie, J. Rahilly and R. Cowie: Hiberno-English intonation: aspects of Belfast intonation

M. Filippula (Joensuu, Finland): New directions in the study of Hiberno-English

R. Gregg (UBC, Vancouver): True dental consonants in Hiberno-English and Ulster-Scots dialects

J. Harris and J. Kaye (UCL/SOAS) : Government and Charm phonology and dental consonants

J. Kallen (TDC): Towards a realistically variable syntax : Hiberno-English tense and aspect

P. Kelly (UC Galway): Afterthoughts on after DO+ing

D. O'Baoill (ITE Dublin): Phonetic features and distribution in consonant system of Irish English

R. O'hUrdail (UC Cork): Phonological underdifferentiation in dialects of Cork English

S. O'Maolain (UC Galway): A phoneme cluster in Irish English

S. Ureland (Mannheim): Penetration of standard languages in the Connemara Gaeltacht 


\section{JOURNAL OF LINGUISTICS}

VOLUME 251989

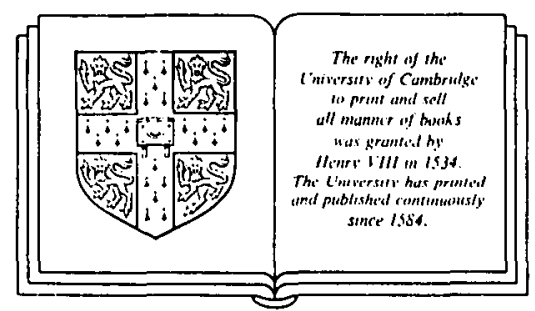

Published for the

Linguistics Association of

Great Britain by

CAMBRIDGE UNIVERSITY PRESS

Cambridge

New York Port Chester Melbourne Sydney 
PUBLISHED BY

THE PRESS SYNDICATE OF THE UNIVERSITY OF CAMBRIDGE

The Pitt Building, Trumpington Street, Cambridge CB2 IRP

32 East 57th Street, New York, NY 10022, USA

Io Stamford Road, Oakleigh, Melbourne 3166, Australia

(C) Cambridge University Press 1989

Printed in Great Britain by the University Press, Cambridge 


\section{CONTENTS}

ARTICLES, NOTES AND DISCUSSIONS

PAGE

B. AARTS: Verb-preposition constructions and small clauses in English

F. BeUKMA \& P. CoOpmans: A Government-Binding perspective on the imperative in English

G. BoolJ: On the representation of diphthongs in Frisian

R. D. BORSLEY: An HSPG approach to Welsh

N. BURTON-RoBERTS: On Horn's dilemma: presupposition and negation

M. Charette: The Minimality Condition in phonology

S. DAvIS: On a non-argument for the Rhyme

E. FUDGE: Syllable structure: a reply to Davis

L. HAEGEMAN: Be going to and will: a pragmatic approach

J. HARRIS: Towards a lexical analysis of sound change in progress

K. Hengeveld: Layers and operators in Functional Grammar

R. A. Hudson: Gapping and grammatical relations

A. S. S. MARMARIDOU: Proper names in communication

R. SALKIE: Perfect and pluperfect: what is the relationship?

I. M. SCHLESINGER : Instruments as agents: on the nature of semantic relations

W. VAN DER WURFF: The syntax of participial adjuncts in Eastern Bengali

N. BURTON-RobertS: R. VAN DER SANDT, Context and presupposition

S. C. LeVINSON: D. SPERBER \& D. WILSON, Relevance: communication and cognition

REVIEWS, SHORTER NOTICES AND BRIEF MENTIONS

H. ANDERSON: Sandhi phenomena in the languages of Europe (Walker)

M. E. BeCKMAN: Stress and non-stress accent (Ladd)

D. BIBER: Variation across speech and writing (Jucker)

A. CARSTAIRS: Allomorphy in inflexion (Jensen) 
W. U. Dressler, W. Mayerthaler, O. Panagl \& W. U. Wurzel:

Leitmotifs in Natural Morphology (Carstairs)

A. M. Di Sciullo \& E. Williams: On the definition of word (Carstairs) 225

B. A. Fox: Discourse structure and anaphora (Ariel)

R. GRISHMAN: Computational linguistics (Russell)

T. GunJI: Japanese Phrase Structure Grammar: a unification based approach (Bennett)

M. HAMMOND \& M. NOONAN (eds): Theoretical morphology: approaches in modern linguistics (Bauer)

M. HARRIS \& P. RAMAT (eds): Historical development of auxiliaries (Bertinetto)

J. HeAth: Ablaut and ambiguity: phonology of a Moroccan Arabic dialect (Wise)

R. HENDRICK: Anaphora in Celtic and universal grammar (Borsley)

H. Hoenigswald \& L. F. Weiner (eds): Biological metaphor and cladistic classification: an interdisciplinary approach (Lass)

R. HogG \& C. B. MCCully: Metrical phonology: a coursebook (Vogel)

C. Holes: Language variation and change in a modernising Arab state: the case of Bahrain (Kaye)

J. Holm: Pidgins and creoles. Vol. I. Theory and structure (Mühlhäusler)

G. HorRocks: Generative grammar (Tallerman)

G. J. HuCK \& A. E. OJEDA (eds): Discontinuous constituency (Cann)

257

E. L. KEENAN: Universal grammar: 15 essays (Mallinson)

259

J. Koster: Domains and dynasties (Borsley)

R. LASS: The shape of English (Hogg)

526

264

W. P. LeHMANN: Language typology 1985: papers from the linguistic typology symposium, Moscow (Mallinson)

P. Lieberman \& S. E. Blumstein: Speech physiology, speech perception and acoustic phonetics (Hawkins)

M. LUMSDEN: Existential sentences: their structure and meaning (Lyons)

I. A. MeL'CuK: Dependency syntax: theory and practice (Miller)

J. Norman: Chinese (Sampson)

J. B. Pierrehumbert \& M. E. Beckman: Japanese tone structure (Ladd)

A. RADFORD: Transformational grammar (Friedin)

U. REYLE \& C. ROHRER (eds): Natural language parsing and linguistic theories (Briscoe)

L. SADLER: Welsh syntax: a Government-Binding approach (Tallerman)

D. SCHIFFRIN : Discourse markers (Owen) 
S. Shaumyan: A semiotic theory of language (Hearne)

D. I. SLOBIN (ed.): The cross-linguistic study of language acquisition (Fletcher)

B. SZYMANEK: Categories and categorization in morphology (Carstairs) 506

M. L. ZUBIZARRETA: Levels of representation in the lexicon and in the syntax (Haegeman)

EDITORIAL NOTE

Publications ReCEIVED 


\section{THE LINGUISTICS ASSOCIATION}

The Linguistics Association of Great Britain was founded in 1959 to promote the study of linguistics and to provide for its members both a forum for discussion and facilities for cooperation in furtherance of their interest in linguistics. The Association holds annual spring and autumn meetings, at which original papers are presented in plenary sessions and in workshops devoted to special interests.

\section{COMMITTEE MEMBERS}

President: Professor Ruth M. Kempson, Dept. of Linguistics, Room 531, School of Oriental and African Studies, Malet Street, London WC IE $7 \mathrm{HP}$.

Hon. Secretary: Dr Richard Coates, School of Cognitive \& Computing Sciences, University of Sussex, Falmer, Brighton BN $19 \mathrm{QN}$.

Membership Secretary: Dr R. D. Borsley, Dept. of Linguistics, University College of North Wales, Bangor, Gwynedd LL 57 2DG.

Meetings Secretary: Dr Jennifer Coates, Dept. of English, Southlands College, Roehampton Institute, London SWr 9 $5 \mathrm{NN}$.
Persons interested in linguistics are eligible for election as members, subject to the approval of the Committee. Subscribing members may receive the Fournal of Linguistics at a substantial discount. Application forms for membership may be obtained from the membership Secretary, Dr Andrew Crompton, Dept. of Linguistics, University of Nottingham, University Park, Nottingham $\mathrm{NE}_{7}$ 2RD.

Treasurer: Dr Ronald Cann, Dept. of Linguistics, University of Edinburgh, Adam Ferguson Building, 40 George Square, Edinburgh EH8 9LL.

Assistant Secretary: Robyn Carston, Dept. of Phonetics and Linguistics, University College London, Gower Street, London WCrE 6B'T.

BLN Editor: Dr Colin Biggs, Dept. of Linguistic Science, The University, Whiteknights, Reading RG6 2AA.

\section{BRITISH NATIONAL COMMITTEE FOR LINGUISTICS}

The Chairman is Professor John Lyons, Trinity Hall, Cambridge, CB2 ITJ, and the LAGB representatives are Dr Richard Coates, School of Social Sciences, University of Sussex, Falmer, Brighton BNI $9 \mathrm{QN}$ and Professor J. R. Hurford, Dept. of Linguistics, University of Edinburgh, Adam Ferguson Building, George Square, Edinburgh EH8 gLL. 


\section{CONTENTS}

ARTICLES

B. AARTS: Verb-preposition constructions and small clauses in English 277

L. HaEgeman: Be going to and will: a pragmatic account 291

G. Bools: On the representation of diphthongs in Frisian $\quad 319$

R. D. BORSLEY: An HPSG approach to Welsh 333

A. S. S. Marmaridou: Proper names in communication 355

W. VAN DER WURFF: The syntax of participial adjuncts in Eastern Bengali 373

F. Beukema \& P. Coopmans: A Government-Binding perspective on the imperative in English

REVIEW ARTICLES

N. Burton-Roberts: R. VAn der Sandt, Context and presupposition

S. C. Levinson: D. Sperber \& D. Wilson, Relevance: communication and cognition

REVIEWS

D. I. SLOBIN (ed.): The cross-linguistic study of language acquisition (Fletcher)

D. BIBER: Variation across speech and writing (Jucker)

M. L. ZuBIzARRETA: Levels of representation in the lexicon and in the syntax (Haegeman)

H. Hoenigswald \& L. F. Weiner (eds): Biological metaphor and cladistic classification: an interdisciplinary approach (Lass)

B. A. Fox: Discourse structure and anaphora (Ariel)

R. HENDRICK : Anaphora in Celtic and universal grammar

M. Hammond \& M. NoOnan (eds): Theoretical morphology': approaches in modern linguistics (Bauer)

B. SzymaneK: Categories and categorization in morpholog!' (Carstairs)

A. RADFORD: Transformational grammar (Friedin)

J. B. Pierrehumbert \& M. E. Beckman: Japanese tone structure (Ladd)

J. Koster: Domains and dinasties (Borsley)

SHORTER NOTICES

P. Lieberman \& S. E. Blumstein: Speech physiology, speech perception and acoustic phonetics (Hawkins)

U. REyLE \& C. Rohrer (eds): Natural language parsing and linguistic theories (Briscoe)

M. Harris \& P. Ramat (eds): Historical development of auxiliaries (Bertinetto)

H. ANDERSEN: Sandhi phenomena in the languages of Europe (Walker)

W. P. LeHMANN: Language typology 1985 : papers from the linguistic typolog, symposium, Moscow (Mallinson)

PUBLICATIONS RECEIVED 